\title{
Farklı Meslek Çalışanı Ebeveynlerin Okul Öncesi Öğretmenlerine İlişkin Görüşlerine Nitel Bir Bakış*
}

\section{A Qualitative Perspective on the Opinions of Parents from Different Professions on Preschool Teachers}

\author{
Bengü TÜRKOĞLU**
}

\begin{abstract}
Received: 31 May 2018
Research Article

Accepted: 20 September 2018

ABSTRACT: In this study, the opinions of parents, who have children in the preschool period and work in different professions, on preschool teachers were evaluated. The study group of the research consisted of 20 mothers and 18 fathers, 38 parents in total, who had children in the preschool period, graduated from university and worked in the state sector in different professions. In this study, the phenomenology pattern, one of the qualitative research techniques, was used. The data were collected using the "Personal Information Form" including questions for parents and the semi-structured "Parent Interview Form", which was prepared by the researcher and contained open-ended questions. The Parent Interview Form consisted of questions regarding the status of preschool teachers in the society, their difference from other teaching areas, their personality traits, the professional skills they must have, the way they prepare children for the first grade in primary school, their work hours and dialogues with families. According to the findings of the study, parents stated that preschool teachers had a position far from the value they deserved and provided children with life skills differently from other teaching areas, they must be kindhearted and create different learning environments, they prepared children for the primary school adequately, their working hours were too long, and they must be in cooperation with families continuously. This study is significant in terms of the determination of parents' expectations about preschool teachers, making different suggestions and enabling cooperation between the teacher and the parent as a result of the data obtained.
\end{abstract}

Keywords: preschool teachers, preschool period, an employee of a different profession, parents' opinions.

ÖZ: Bu çalışma ile okul öncesi dönemde çocuğu olan farklı meslek çalışanı ebeveynlerin okul öncesi öğretmenlerine dair görüşleri değerlendirilmiştir. Araştırmanın çalışma grubunu okul öncesi dönemde çocuğu olan, üniversite mezunu ve devlet sektöründe çalışan farklı meslek gruplarından 20 anne ve 18 baba olmak üzere toplam 38 ebeveyn oluşturmuştur. $\mathrm{Bu}$ araştırmada, nitel araştırma tekniklerinden biri olan olgu bilim (fenomenoloji) deseni kullanılmıştır. Veriler ebeveynlere yönelik soruları içeren "Kişisel Bilgi Formu" ve araştırmacı tarafından hazırlanan, açık uçlu sorulardan oluşan yarı yapılandırılmış "Ebeveyn Görüşme Formu” kullanılarak toplanmıştır. Ebeveyn Görüşme Formu; okul öncesi öğretmeninin toplumdaki konumu, diğer öğretmenlik alanlarından fark1, kişisel özellikleri, sahip olması gereken mesleki beceriler, çocukları ilkokul birinci sınıfa hazırlama durumu, çalışma süreleri ve ailelerle diyaloğuna dair sorulardan oluşmaktadır. Araştırmanın bulgularına göre ebeveynler, okul öncesi öğretmenlerinin hak ettiği değerden uzak bir konumda olduğunu, diğer öğretmenlik alanlarından farklı olarak çocuklara yaşam becerileri kazandırdıklarını, sevecen olmaları ve farklı öğrenme ortamları oluşturmaları gerektiğini, çocukları ilkokula yeterli düzeyde hazırladıklarını, çalışma sürelerinin oldukça uzun olduğunu ve ailelerle sürekli işbirliği halinde olmaları gerektiğini ifade etmişlerdir. Bu çalışma okul öncesi öğretmenlerine yönelik ebeveynlerin beklentilerinin ve düşüncelerinin tespit edilmesi, çeşitli önerilerde bulunulması ve elde edilen veriler neticesinde öğretmen, ebeveyn iş birliğinin sağlanması bakımından önem taşımaktadır.

Anahtar kelimeler: okul öncesi öğretmenleri, okul öncesi dönem, farklı meslek çalışanı, anne-baba görüşleri.

\footnotetext{
* A part of this work was presented as an oral presentation at International Congress on Science and Education in Afyonkarahisar on March, 23-25, 2018.

*** Corresponding Author: Corresponding Author: Asst. Prof. Dr., Necmettin Erbakan University, Konya, Turkey, turkoglubengu@gmail.com
}

Citation Information

Türkoğlu, B. (2018). Farklı meslek çalışanı ebeveynlerin okul öncesi öğretmenlerine ilișkin görüşlerine nitel bir bakış. Kuramsal Eğitimbilim Dergisi [Journal of Theoretical Educational Science], 11(5), 100-124. 


\section{Giriş}

Öğretme-öğrenme işinin insanlık tarihi kadar eski olduğu bilgisinden hareketle öğretmenlik mesleğinin dünyanın en eski mesleklerinden biri olduğu söylenebilir (Oktay, 1991). Öğretmen, eğitim kurumlarında eğitsel amaçları gerçekleştirmede çocukların veya gençlerin zihinsel, duyuşsal ve psikomotor gelişimine katkıda bulunan, öğrenme yaşantılarına rehberlik eden, yön veren, anne-babalara kılavuzluk eden, genel kültür sahibi, öğreteceği bilimsel dalda uzmanlaşmış kişi olarak tanımlanabilir (Başaran, 1993; Duman, 1991; Gündüz, 2003). Öğretmenliği, 1739 sayılı Temel Eğitim Kanunu "Devletin eğitim, öğretim ve bununla ilgili yönetim görevlerini üzerine alan özel bir ihtisas mesleği" olarak; Orta Tedrisat Muallimleri Kanunu ise "devletin umumi hizmetlerinden talim ve terbiye vazifesini üzerine alan, müstakil sınıf ve derecelere ayrılan bir meslek" olarak tanımlamaktadır (Akyüz, 2008).

Önceleri bir "çocuk bakımı" olarak algılanan öğretmenlik mesleği, bugün bilimsel, akademik ve uzmanlık boyutlarının önem kazandığı seçkin ve profesyonel bir meslek haline gelmiştir ve toplumdaki herkes için nitelikli eğitimin en temel belirleyicisi öğretmendir (Gök, 2003; Hacıŏglu \& Alkan, 1997). Bir işte profesyonel olmak özel bir eğitim neticesinde kazanılmış ve belirli standartlar yerine getirilerek toplum hizmetine sunulmuş yüksek bilgi düzeyini, mesleki onuru gerektirir (CarrSaunders \& Wilson, 1944; Svensson, 2006). Sönmez ve diğerleri (2000) profesyonel bir meslek anlayışında; bilimsellik, çok boyutlu genel bir formasyonun alınması, uzmanlaşma, yaşam boyu eğitimin ve gelişimin esas alınması, ilgili tarafların iş birliği, bilimsel, teknolojik ve uygulama boyutlarının bütünleştirilmesi gibi niteliklerin temel alınması gerektiğini belirtmektedir. Profesyonel bir mesleğin temel koşulları ise mesleğinde sistematik kuramsal yapıya aşina olma, mesleğinde otorite olma, toplumca onaylanma, mesleki etiği izleme ve mesleki kültüre sahip olma olarak sıralanabilir (Greenwood, 1967; Akt: Sünbül, 1996, ss. 7-8).

Bir eğitim sisteminin en önemli görevi nitelikli öğretmen yetiştirmektir. Çünkü eğitim sisteminin başarısı, sistemin en temel öğesi olan öğretmen niteliklerine bağlıdır. Yani bir öğretim kurumu ne kadar mükemmel olursa olsun, bu öğretim kurumunda görev alan öğretmenler gerekli niteliklere sahip olmadıkça, öğretim sürecinde beklenen fayda sağlanamayacaktır (Çeliköz \& Çetin, 2004; Gökçe, 1997; Kavcar, 1999; Luke, Luke, \& Mayer, 2000). Nitelikli bireyler yetiştirilmesi suretiyle toplumların gelişmesinde ve öğrenci başarısında en belirleyici etken öğretmenlerdir (Barber \& Mourshed, 2007). Başarılı ve etkili bir öğretmende bulunması gereken özellikleri Senemoğlu (2001), hem iyi bir konu alan bilgisine, hem de öğretmenlik formasyon bilgisine sahip olmak, öğretmeye güdülenmek, öğretmenliğe gönül vermek ve bu özellikleri de deneyimle güçlendirmek olarak sıralarken; Stephens ve Crawley (1994) ise konusunu iyi bilme, konusunu iyi öğretme, konusunu etkili ve düzenli bir ortamda öğretme, öğrencilerinin seviye ve performans kayıtlarını sistematik olarak tutma, yaşam boyu mesleki gelişime inanma olarak beş nitelikten bahsetmektedirler. Shulman'a (1986) göre, öğretmenin öğretebilmesi için anlaması gereken öğretmenlik bilgisiyle alakalı yedi alan vardır. Bunlar; genel pedagojik bilgi, öğrenci özellikleri bilgisi, alan bilgisi, pedagojik alan bilgisi, müfredat bilgisi, eğitim sistemi bilgisi ve eğitim hedefleri bilgisidir. $\mathrm{Bu}$ bilgi alanları, öğretmenlerin bilgi sahibi olmaları gereken alanları vurgulama açısından oldukça değerlidir. 
Öğretmenlerin etkili ve başarılı olmasında kişisel ve mesleki niteliklere sahip olmaları büyük önem taşır. Öğretmenlerin sahip olması gereken kişisel özellikler; açık fikirlilik, kendine güven, mesleki ve demokratik ideallere bağlılık, liderlik, sürekli öğrenme ve gelişmeye açıklık, yaratıcı düşünme, iyi ahlak, iletişim, sevgi, sabır, hoşgörü, espri anlayışı, adaletli ve tarafsız davranma, başkalarının yetişmesine katkıda bulunma olarak sıralanabilir. Ayrıca öğretmenlerin mesleğe ilişkin sahip olmaları gereken özellikler ise; eğitimin ve öğretmenlik mesleğinin insan yaşamındaki ve toplumdaki önemini anlama, eğitim ve meslekle ilgili yasa ve yönetmelikleri bilme, bunlara uygun davranma, mesleki inanç ve bağl1lık duygusuna sahip olma, mesleğin değer ve normlarına uygun davranma olarak belirtilebilir. Bunların yanı sıra mesleki kuruluşları tanıma ve destek olma, mesleğin toplumsal statüsünü yükseltmeye katkıda bulunma, eğitim personeli, öğrenci, veli ve is çevreleri ile uyum içinde olmak öğretmenlerin sahip olmaları gereken diğer mesleki özelliklerdir. Bir öğretmenin kişisel nitelikleri ne kadar olumlu olursa olsun mesleki niteliklere sahip değilse ya da tam tersi durum söz konusu olduğunda bireyin etkili bir öğretmen olması beklenemez (Erden, 1998; Gündüz, 2003).

Bireylerin var olan potansiyellerini gerçekleştirebilmelerine yardımcı olmaya yönelik gayreti ve evrensel, yerel kültürel mirasın iletilmesindeki aracı rolü nedeniyle öğretmenlik mesleği her zaman tüm toplumlarda diğer meslek gruplarından farklı bir yere sahip olmuştur (Güven, 2010). Öğretmenlerin, eğitim öğretimin kalitesi ve öğrenci başarısı üzerindeki rolü bu kadar önemli olmasına rağmen öğretmenlere özellikle de okul öncesi öğretmenlerine toplumun tüm kesimlerinden hak ettikleri değerin verildiğini söylemek oldukça zordur. Yapılan çalışmalar öğretmenlerin düşük ücret, statü baskısı, iş yükü, iş tatminsizliği, istihdam, aidiyet, kontrol, adalet ve yönetimsel sorunlar yüzünden sıkıntı yaşadıklarını ortaya koymaktadır (Avcı \& Seferoğlu, 2011; Güven, 2010; Tekışık, 1987; Yaman, Yaman, \& Eskicumalı, 2001). Ayrıca öğretmenlerin sorunlarına karşı toplum, devlet ve medya düşük bir duyarlılığa sahiptir (Yurdakul, Gür, Çelik, Kurt, \& Olçum, 2016).

Öğretmenlik branşları içerisinde okul öncesi öğretmeni çocuğun aileden sonra yüreğine dokunan ilk kişi olması sebebiyle çocuğun yaşantısında oldukça önemli bir yere sahiptir. Kadınların çalışma hayatına katılmaları ile birlikte okul öncesi döneme dair ciddi politikalar geliştirilmiş ve yasal düzenlemeler doğrultusunda kurumsal gelişmeler hız kazanmıştır (Aslanargun \& Tapan, 2011). Okul öncesi eğitim; çocukların doğumdan, ilköğretime başladıkları güne kadar geçirdikleri dönemi içeren, bireysel farklılıklarının ve yeteneklerinin göz önünde bulundurularak zengin uyarıcılı çevre olanaklarının sağlandığı, daha sonraki yaşamlarında önemli bir yeri olan, bedensel, psikomotor, sosyal-duygusal, zihinsel ve dil gelişimlerinin toplumun milli, manevi ve kültürel değerleri doğrultusunda yönlendirildiği, büyük ölçüde tamamlandığı, yaşam boyu devam edecek öğrenme sürecinin temellerinin atıldığı, yaratıcı yönlerinin ortaya çıkarıldığı, kişilik temellerinin atıldığı sistemli bir gelişim ve eğitim sürecidir (Aral, Kandır, \& Can-Yaşar, 2000; Oğuzkan \& Oral, 1997; Tuğrul, 2006; Zembat, 1992). Bu sürecin sağlıklı bir şekilde geçirilmesinde ve nitelikli insan yetiştirilmesinde çocuğa ilk eğitimin verildiği okul öncesi eğitim kurumlarının ve özellikle okul öncesi öğretmenlerinin etkisi yadsınamaz bir gerçektir. Mesleğini severek icra eden okul öncesi öğretmenleri oluşturdukları eğitim ortamlarıyla çocuklar üzerinde olumlu etkiler bırakarak sağlıklı ve nitelikli nesiller yetişmesinde büyük önem taşımaktadır. $\mathrm{Bu}$ 
noktada ebeveynlerin okul öncesi öğretmenlerine yönelik görüşleri, algıları, onlara güvenmeleri, destek olmaları okul öncesi öğretmenlerinin mesleklerine bakış açılarını, etkin eğitim ortamlarının oluşturulmasını da etkilemektedir (Dönmez, 1992; Oktay, 2004).

\section{Araştırmanın Amacı}

Bu çalışmanın genel amacı, okul öncesi dönemde çocuğu olan farklı meslek çalışanı ebeveynlerin okul öncesi öğretmenlerine dair görüşlerini ortaya koymaktır.

$\mathrm{Bu}$ genel amaç doğrultusunda aşağıdaki sorulara cevap aranmıştır:

1. Okul öncesi öğretmeninin toplumdaki konumu nedir?

2. Okul öncesi öğretmenliği diğer öğretmenlik alanlarından hangi açılardan farklıdır?

3. Okul öncesi öğretmeninin kişisel özellikleri nasıl olmalıdır?

4. Okul öncesi öğretmeninin yeterli olması için hangi mesleki becerilere sahip olmas1 gerekir?

5. Okul öncesi öğretmeni çocukları ilkokul birinci sınıfa ne kadar hazırlayabilir?

6. Okul öncesi öğretmenlerinin çalışma süreleri hakkında ne düşünüyorsunuz?

7. Okul öncesi öğretmeninin ailelerle diyaloğu nasıl olmalıdır?

\section{Araştırmanın Önemi}

Çocuğun bakımının ve eğitiminin başladığı ilk yer hiç şüphesiz aile ortamıdır. Çocuk için ailede başlayan eğitim süreci okul öncesi eğitim kurumunda devam eder, ancak çocukların yetiştirilmesinde ebeveynlerin rolü hala çok önemli ve büyüktür. $\mathrm{Bu}$ sebepten okul aile iş birliğinin önemi kesinlikle yadsınamaz. Ebeveyn ve ailenin eşgüdümlü hareket etmesi çocuk için en etkin eğitim metodudur (İşmen \& Yıldız, 1996). Okul öncesi öğretmenlerinin aileleri yetersiz oldukları konularda destekleyebilmeleri, ebeveynlerin ihtiyaç duydukları durumlarda öğretmenlerden yardım isteyebilmeleri için ailelerin okul öncesi öğretmenlerine yönelik olumlu görüşlerinin olması ve onlara güven duymaları öncelikli şarttır. Bu araştırmada okul öncesi dönemde çocuğu olan farklı meslek çalışanı ebeveynlerin okul öncesi öğretmenlerine dair görüşlerine başvurulmuştur. $\mathrm{Bu}$ çalışmayla okul öncesi öğretmenlerine yönelik toplumdaki üniversite mezunu, çalışan ebeveynlerin düşünce yapısına ulaşılmaya çalışılmış, bilinç düzeyleri ve farkındalıkları öğrenilmek istenmiştir. Alan yazın incelendiğinde farklı meslek çalışanı ebeveynlerin okul öncesi öğretmenleri hakkındaki görüşlerine yer veren bu tarz bir araştırmaya rastlanılmamıştır. Bu bağlamda bu çalışma okul öncesi öğretmenlerine yönelik ebeveynlerin beklentilerinin ve düşüncelerinin incelenmesi ve çeşitli önerilerde bulunulması bakımından önem arz etmektedir. 


\section{Yöntem}

\section{Araştırmanın Deseni}

$\mathrm{Bu}$ araştırmada, nitel araştırma tekniklerinden biri olan olgu bilim (fenomenoloji) deseni kullanılmıştır. Olgular; yaşadığımız dünyada olaylar, deneyimler, algılar, yönelimler, kavramlar ve durumlar gibi biçimlerde karşımıza çıkabilmektedir. Olgu bilim deseni, farkında olduğumuz ancak derinlemesine ve ayrıntılı bir anlayışa sahip olmadığımız olgulara odaklanmakta ve daha çok sübjektif görüşün betimleme özelliğine sahip ve bireysel farklılıkları göz önünde tutan yeni bir araştırma anlayışı gerektirmektedir (Çepni, 2012; Yıldırım \& Şimşek, 2011). Bu araştırma, okul öncesi dönemde çocuğu olan farklı meslek çalışanı ebeveynlerin "okul öncesi öğretmeni” kavramına ilişkin görüşlerini ayrıntılı şekilde ve farklı yönleriyle ortaya koymak, betimlemek ve ayrıntılı bir anlayışa sahip olmak amacıyla olgu bilim deseninde yürütülmüştür.

\section{Çalışma Grubu}

$\mathrm{Bu}$ araştırmada okul öncesi öğretmeni kavramı okul öncesi dönemde çocuğu olan farklı meslek çalışanı ebeveynlerin görüşleri doğrultusunda incelenmiştir. Çalışma grubunun seçiminde amaçlı örneklem yöntemlerinden ölçüt örnekleme yöntemi kullanılmıştır. Bu örneklem yönteminde temel anlayış önceden belirlenmiş bir dizi ölçütü karşılayan bütün durumların çalışılmasıdır. Sözü edilen ölçüt veya ölçütler araştırmacılar tarafından oluşturulabilir ya da daha önceden hazırlanmış ölçüt listeleri kullanılabilir (Yıldırım \& Şimşek, 2011). Bu bağlamda örnekleme alınacak katılımcılar belirlenirken, üniversite mezunu olmaları, devlet sektöründe çalışmaları ve okul öncesi eğitime devam eden çocuklarının olması ölçüt olarak belirlenmiştir. Buna göre araştırmanın çalışma grubunu bahsedilen ölçütleri karşılayan farklı meslek gruplarından toplam 38 ebeveyn oluşturmuşstur.

Tablo 1

Ebeveynlere İlişkin Bilgiler

\begin{tabular}{llllll}
\hline Ebeveynler & Cinsiyet & Yaş & Öğrenim Durumu & Meslek & $\begin{array}{l}\text { Hizmet } \\
\text { Yllı }\end{array}$ \\
\hline E1 & Kadın & 37 & Lisans & Hemşire & $11-15$ \\
E2 & Erkek & 35 & Lisans & Diş Hekimi & $11-15$ \\
E3 & Kadın & 38 & Yüksek Lisans & Mimar & $11-15$ \\
E4 & Erkek & 32 & Yüksek Lisans & Mühendis (İņaat) & $6-10$ \\
E5 & Kadın & 42 & Lisans & Eczacı & $16-20$ \\
E6 & Kadın & 31 & Lisans & Bankacı & $6-10$ \\
E7 & Erkek & 31 & Yüksek Lisans & Mühendis (Bilgisayar) & $6-10$ \\
E8 & Erkek & 33 & Lisans & Doktor & $11-15$ \\
E9 & Kadın & 37 & Lisans & Mühendis (Endüstri) & $16-20$ \\
E10 & Erkek & 35 & Lisans & Avukat & $11-15$ \\
E11 & Kadın & 33 & Lisans & Hemşire & $11-15$ \\
& & & & &
\end{tabular}




\begin{tabular}{|c|c|c|c|c|c|}
\hline E12 & Kadın & 31 & Lisans & Bankacı & $6-10$ \\
\hline E13 & Erkek & 42 & Lisans & Veteriner & $16-20$ \\
\hline E14 & Erkek & 43 & Lisans & Subay & $21-25$ \\
\hline E15 & Kadın & 36 & Lisans & Diş Hekimi & $11-15$ \\
\hline E16 & Erkek & 34 & Lisans & Polis Memuru & $6-10$ \\
\hline E17 & Kadın & 31 & Doktora & Doktor & $6-10$ \\
\hline E18 & Kadın & 35 & Lisans & Hâkim & $11-15$ \\
\hline E19 & Erkek & 31 & Doktora & Öğretim Üyesi & $6-10$ \\
\hline E20 & Kadın & 41 & Doktora & Doktor & $16-20$ \\
\hline E21 & Kadın & 37 & Yüksek Lisans & Mühendis (Makine) & $11-15$ \\
\hline E22 & Kadın & 35 & Doktora & Öğretim Üyesi & $11-15$ \\
\hline E23 & Erkek & 45 & Lisans & Komiser & $21-25$ \\
\hline E24 & Erkek & 35 & Lisans & Subay & $11-15$ \\
\hline E25 & Kadın & 32 & Yüksek Lisans & Mimar & $11-15$ \\
\hline E26 & Kadın & 31 & Lisans & Veteriner & $6-10$ \\
\hline E27 & Erkek & 31 & Lisans & Mimar & $6-10$ \\
\hline E28 & Erkek & 33 & Lisans & Hâkim & $11-15$ \\
\hline E29 & Kadın & 31 & Lisans & Avukat & $6-10$ \\
\hline E30 & Erkek & 35 & Lisans & Polis Memuru & $11-15$ \\
\hline E31 & Kadın & 33 & Lisans & Hemşire & $11-15$ \\
\hline E32 & Erkek & 31 & Lisans & Subay & $6-10$ \\
\hline E33 & Erkek & 42 & Lisans & Eczacı & $16-20$ \\
\hline E34 & Erkek & 44 & Doktora & Doktor & $21-25$ \\
\hline E35 & Kadın & 40 & Doktora & Öğretim Üyesi & $16-20$ \\
\hline E36 & Kadın & 34 & Lisans & Bankacı & $11-15$ \\
\hline E37 & Kadın & 40 & Lisans & Diyetisyen & $16-20$ \\
\hline E38 & Erkek & 45 & Lisans & Avukat & $21-25$ \\
\hline
\end{tabular}

Araştırmanın çalışma grubunu oluşturan ebeveynlerin 20'si (\%53) kadın, 18'i (\%47) erkektir. Ebeveynlerin 23'ü (\%61) 31-35, 7'si (\%18) 36-40 ve 8'i (\%21) 41-45 yaş aralığındadır. Ebeveynlerin 27'si (\%71) lisans, 5'i (\%13) yüksek lisans ve 6's1 (\%16) doktora mezunudur. Ebeveynlerin 11'i (\%29) 6-10 y1llik, 16's1 (\%42) 11-15 yıllık, 7'si (\%18) ise 16-20 yıllık, 4’ü (\%11) 21-25 y1llık mesleki kıdeme sahiptir.

\section{Veri Toplama Araçları}

Araştırmada veriler ebeveynlere yönelik soruları içeren "Kişisel Bilgi Formu" ve açık uçlu sorulardan oluşan yarı yapılandırılmış "Ebeveyn Görüşme Formu" kullanılarak toplanmıştır. Kişisel Bilgi Formu; ebeveynlerin cinsiyeti, yaşı, öğrenim durumu, mesleği ve mesleki hizmet yılına dair bilgileri inceleyen soruları içermektedir. Ebeveyn Görüşme Formu; okul öncesi öğretmeninin toplumdaki konumu, diğer öğretmenlik alanlarından farkı, kişisel özellikleri, sahip olması gereken mesleki 
beceriler, çocukları ilkokul birinci sınıfa hazırlama durumu, çalışma süreleri ve ailelerle diyaloğuna dair sorulardan oluşmaktadır. Yarı yapılandırılmış görüşmeler açıklığa kavuşturulmak istenen sorular yoluyla katılımcıların duygu ve düşüncelerini açıkladığı, böylece katılımcılardan verilerin toplandığı, ne tam yapılandırılmış görüşmeler kadar katı, ne de yapılandırılmamış görüşmeler kadar esnek olan görüşme çeşididir (Büyüköztürk, Çakmak, Akgün, Karadeniz \& Demirel, 2009; Karasar,2009; Merriam, 2015). Görüşme soruları hazırlanmadan önce alan yazın taraması yapılmış, kapsam geçerliğini sağlayabilmek için üç uzmandan görüş alınmış ve yedi sorudan oluşan yarı yapılandırılmış görüşme formu oluşturulmuştur. Görüşme soruları uygulama öncesinde 4 farklı meslek çalışanı anne ve babaya sorularak anlaşılırlığı kontrol edilmiş ve sorulara son şekli verilmiştir. Böylece soru maddelerinin iç geçerliği de sağlanmıştır. Ön uygulama yapılan ebeveynlerden elde edilen veriler araştırmaya dâhil edilmemiştir.

\section{Verilerin Toplanması}

Veriler toplanmadan önce ebeveynlere araştırmada katılımcı olmaya ilişkin gönüllü olup olmadıkları sorulmuş, gönüllü olan 38 ebeveynin her biriyle farklı tarihlerde yüz yüze ve bireysel görüşmeler yapılmıştır. Görüşmeler 16 Ocak-20 Şubat 2018 tarihleri arasında gerçekleştirilmiştir. Görüşmenin başında ebeveynlere araştırmanın amacı detaylı bir şekilde açıklanmış ve görüşme formundaki sorulara samimi cevap vermelerinin önemi üzerinde durulmuştur. Görüşmelerde ses kayıt cihazı kullanılmış ve daha sonra kayıtlar metne dönüştürülmüştür. Görüşme sorularına geçilmeden önce katılımcıların demografik bilgileri kayıt altına alınmıştır. Görüşmeler en fazla 40 dakika sürmüştür. Görüşüne başvurulan farklı meslek çalışanı ebeveynler için “E1, E2, E3...” kodları kullanılmıştır.

\section{Verilerin Analizi}

Ebeveynlerle yapılan görüşmelerden elde edilen veriler, nitel veri analiz tekniklerinden biri olan betimsel analiz tekniği kullanılarak yorumlanmıştır. Betimsel analiz, elde edilen verilerin daha önceden belirlenen temalara göre özetlendiği ve yorumlandığı, neden sonuç ilişkilerinin irdelenerek sonuca ulaşılmasına olanak sağlayan analizlerdir (Yıldırım \& Şimşek, 2011). Bu araştırmada temalar, araştırmanın genel amacını destekleyen alt amaçlardır yani temalar seçilen konu başlıklarından oluşturulmuştur. Elde edilen veriler alt amaçların altında düzenlenmiş ve yorumlanmış kodlardır. Araştırmada güvenirliği sağlamak için aynı alanda çalışan ve nitel araştırmalar konusunda deneyimli başka bir öğretim üyesi tarafından elde edilen veriler kodlanmıştır. İki araştırmacı tarafından yapılan kodlamalara Miles ve Huberman'ın (1994) formülü (Güvenirlik=Görüş birliği/Görüş birliği+Görüş ayrılığı) uygulanmıştır. İki kodlayıcı arasındaki uyum \%91 olarak hesaplanmıştır. Güvenirlik hesaplarının \%70 ve üzeri çıkması yeterli görülmektedir. Ayrıca bulguların iç güvenirliğini ve geçerliğini arttırmak maksadıyla farklı meslek çalışanlarının görüşlerinden doğrudan alıntılar yapılmıştır. Araştırmanın dış geçerliliğini artırmak amacıyla da araştırma süreci ayrıntılı olarak açıklanmaya çalışılmıştır. 


\section{Bulgular}

Araştırmanın bu bölümünde, çalışma grubunda yer alan farklı meslek çalışanı ebeveynlerin okul öncesi öğretmenleri hakkındaki görüşlerini tespit etmek amacıyla ebeveyn görüşme formlarından elde edilen görüşlerin çözümlenmesi sonucunda ortaya çıkan bulgulara yer verilmiştir.

\section{Okul Öncesi Öğretmeninin Toplumdaki Konumu}

Ebeveynlerle yapılan görüşmelerden elde edilen veriler analiz edildiğinde ebeveynler okul öncesi öğretmeninin toplumdaki konumuna ilişkin "hak ettiği değerden uzak bir konumda" ve "değer verilen bir konumda" olarak iki farklı görüş bildirmişlerdir.

Tablo 2

Okul Öncesi Öğretmeninin Toplumdaki Konumu

\begin{tabular}{llccc}
\hline Tema & Kod & $n$ & $f$ & $\%$ \\
\hline \multirow{2}{*}{ Konum } & Hak Ettiği Değerden Uzak Bir Konumda & 38 & 24 & 63 \\
& Değer Verilen Bir Konumda & 38 & 14 & 37 \\
\hline
\end{tabular}

Tablo 2'den de anlaşılacağı üzere görüşmeye katılan ebeveynlerin çoğunluğu okul öncesi öğretmenlerinin toplumda hak ettiği değerden uzak bir konumda olduğuna inanmaktadır.

Okul öncesi öğretmenlerinin hak ettiği değerden uzak bir konumda olduğunu belirten yanıtlara örnekler şu şekildedir:

(E12): “Okul öncesi öğretmenine gereken değer verilmemektedir, çocuklarımızın temelinin atıldığı bu kritik döneme ve öğreticisine kesinlikle kıymet verilmelidir. Sağlam temeli olmayan çocuktan bir şey beklemekte bizlerin hatası olur ilerleyen yıllarda."

(E25): "Evde anne babalar tek bir çocuğun bakımını bile zor yaparken 4-6 yaş aralığında yaklaşık 20-25 tane çocuğun hem gün boyu bakımını hem de eğitimini yapmak kolay bir iş değildir. Daha iyi konumları hak etmektedirler."

(E32): "Çocuğumuza bizden sonra en yakın kişidir bu yüzden bizlerin de onları el üstünde tutup toplumda yüceltmemiz gerekir, ancak ne yazık ki toplumda okul öncesi öğretmeni bakıcı gibi düşünülmektedir."

Okul öncesi öğretmenlerinin değer verilen bir konumda olduğunu belirten yanıtlara örnekler şu şekildedir:

(E1): “Okul öncesi öğretmenlerini diğer branş öğretmenleriyle kıyasladığım zaman gereken ilgiyi ve değeri fazlasıyla gördüklerini düşünüyorum.”

(E23): "Oldukça ideal bir konumda bulunuyorlar ancak çalışma standartları biraz daha iyileştirilebilir."

(E35): "Bence okul öncesi öğretmenliği en iyi konumda bulunan öğretmenlik grubu, diğer öğretmenlerin durumu gerçekten vahim.” 


\section{Okul Öncesi Öğretmenliğinin Diğer Öğretmenlik Alanlarından Farklılıkları}

Ebeveynlerle yapılan görüşmelerden elde edilen verilerin analizinde ebeveynler okul öncesi öğretmenliğinin diğer öğretmenlik alanlarından farklılıklarına yönelik olarak "yaşam becerisi kazandırma", "yumuşak mizaca sahip olma", "farklı ve çeşitli materyaller kullanma" ve "gelişimsel aşamaları bilme" olarak dört farklı görüş bildirmişlerdir.

Tablo 3

Okul Öncesi Öğretmenliğinin Diğer Ö̆̆retmenlik Alanlarından Farklılıkları

\begin{tabular}{llccc}
\hline Tema & Kod & $n$ & $f$ & $\%$ \\
\hline & Yaşam Becerisi Kazandırma & 38 & 18 & 47 \\
& Yumuşak Mizaca Sahip Olma & 38 & 11 & 29 \\
Farklılıklar & Farklı ve Çeşitli Materyaller Kullanma & 38 & 6 & 16 \\
& Gelişimsel Aşamaları Bilme & 38 & 3 & 8 \\
\hline
\end{tabular}

Tablo 3'ten de anlaşılacağı üzere okul öncesi öğretmenliğinin diğer öğretmenlik alanlarından farklılıkları konusunda görüşmeye katılan ebeveynlerin çoğunluğu "yaşam becerisi kazandırma" yönünde fikir beyan etmiştir.

Okul öncesi öğretmenliğinin yaşam becerisi kazandırma yönünden diğer öğretmenlik alanlarından farklı olduğunu ifade eden yanıtlara örneklerden bazıları şöyledir:

(E8): "Okul öncesi öğretmenleri çocukların tuvalet, giyinme gibi günlük ihtiyaçlarına yönelik becerilerinin gelişmesine katkıda bulunur."

(E20): "Okul öncesi öğretmenleri diğer öğretmenlerden farklı olarak diş firçalama, el yıkama gibi hayat boyu devam edecek alışkanlıkların kazandırılmasına yardımcı olur."

Okul öncesi öğretmenliğinin yumuşak mizaca sahip olma yönünden diğer öğretmenlik alanlarından farklı olduğunu belirten yanıtlara örnekler şu şekildedir:

(E15): “Okul öncesi öğretmeni öncelikle çocukları sevmeli, onlara karşı şefkat dolu olmalı ve çocukların psikolojisinden anlayıp her hareketlerine sevecen yaklaşabilmelidir.”

(E28): "Bir okul öncesi öğretmeni diğer branşlara nazaran daha güler yüzlü, sevecen ve anlayışlı olmalı; her çocuğa eşit yaklaşabilmelidir."

Okul öncesi öğretmenliğinin farklı ve çeşitli materyaller kullanma yönünden diğer öğretmenlik alanlarından farklı olduğunu ifade eden yanıtlara örneklerden bazıları şöyledir:

(E5): "Çocukların ihtiyaçlarına uygun olarak elişi kâăıdı, fon kartonu gibi farklı farklı materyaller kullanarak dersi zenginleştirir."

(E30): "Okul öncesi öğretmeni sınıfındaki etkinlikleri esnasında hikâye, masal, boyama kitabı gibi çeşitli kaynakları kullanarak dersini zenginleştirir."

Okul öncesi öğretmenliğinin gelişimsel aşamaları bilme yönünden diğer öğretmenlik alanlarından farklı olduğunu belirten yanıtlara örnekler şu şekildedir:

(E3): “Okul öncesi öğretmenleri çocukların hangi yaş aralığında neyi yapıp neyi yapamayacaklarını daha iyi bildikleri için beklentilerini de buna göre şekillendirirler, diğer alan öğretmenlerinin bu konuda çok yeterli olduklarını düşünmüyorum.” 
(E9): "Okul öncesi öğretmeni çocukların bedensel, zihinsel ve sosyal gelişimini çok iyi bilir, ona göre bir tutum ve tavır içine girer."

\section{Okul Öncesi Öğretmeninin Sahip Olması Gereken Kişisel Özellikleri}

Ebeveynlerle yapılan görüşmelerden elde edilen verilerin analizinde ebeveynler okul öncesi öğretmeninin sahip olması gereken kişisel özelliklere yönelik "sevecen olmak", "güler yüzlü olmak", "hoşgörülü olmak", "sorumluluk sahibi olmak" ve "gelişime açık olmak" olarak beş farklı görüş bildirmişlerdir.

Tablo 4

Okul Öncesi Öğretmeninin Sahip Olması Gereken Kişisel Özellikler

\begin{tabular}{llccc}
\hline Tema & Kod & $n$ & $f$ & $\%$ \\
\hline & Sevecen Olmak & 38 & 12 & 32 \\
& Güler Yüzlü Olmak & 38 & 9 & 24 \\
Kişisel Özellikler & Hoşgörülü Olmak & 38 & 7 & 18 \\
& Sorumluluk Sahibi Olmak & 38 & 6 & 16 \\
& Gelişime Açı Olmak & 38 & 4 & 10 \\
\hline
\end{tabular}

Tablo 4'ten de anlaşılacağı üzere görüşmeye katılan ebeveynlerin çoğunluğu "sevecen olmayı" okul öncesi öğretmeninin sahip olması gereken en önemli kişisel özellik olarak belirtmişlerdir.

Okul öncesi öğretmeninin sahip olması gereken kişisel özelliklerden birinin "sevecen olmak" olduğunu ifade eden yanıtlara örneklerden bazıları şöyledir:

(E10): "Okul öncesi öğretmenleri ilk başta çocukları severek işe başlamalıdır, o zaman çocuklar da onu sevecektir ve işleri daha kolay olacaktır."

(E17): "Bir okul öncesi öğretmeni her şeyden önce sevgiyi bilmeli, çocukları sevmeli ve değer vermelidir."

Okul öncesi öğretmeninin sahip olması gereken kişisel özelliklerden birinin "güler yüzlü olmak" olduğunu ifade eden yanıtlara örneklerden bazıları şöyledir:

(E21): "Okul öncesi öğretmeni öncelikle çocukları sevmeli, sevgisini özellikle yüzüne yansıtmalı, her daim gülümsemeli ve çocukların yanında asla somurtkan bir yüz ifadesi takınmamalıdır."

(E38): "Bir okul öncesi öğretmeni diğer branşlara nazaran çocuklara karşı her daim güler yüzlü davranmalıdır, çocuklara güler yüz gösterirse onlarında güler yüzlü olacağını, gümbür gümbür bir nesil yetişeceğimi unutmamalıdır.”

Okul öncesi öğretmeninin sahip olması gereken kişisel özelliklerden birinin "hoşgörülü olmak" olduğunu ifade eden yanıtlara örneklerden bazıları şöyledir:

(E6): “Okul öncesi öğretmeni çok hoşgörülü olmalıdır, çocukların tüm davranışlarına sabır ve anlayışla yaklaşmalıdır."

(E16): “Okul öncesi öğretmenleri çocuklara disiplin aşılamaya çalışmak yerine hoşgörüyle birçok sorunun çözülebileceğini onlara aşılamalıdır." 
Okul öncesi öğretmeninin sahip olması gereken kişisel özelliklerden birinin "sorumluluk sahibi olmak" olduğunu ifade eden yanttlara örneklerden bazıları şöyledir:

(E24): “Çocukların sorumluluk bilinci kazanabilmesi için öncelikle okul öncesi eğitimcilerinin sorumluluklarının farkında ve sorumluluklarını itinayla yerine getiren bireyler olması gerekmektedir."

(E37): "Her şeyden önce bir okul öncesi öğretmeni görev bilinci taşıyan ve bu bilinci çocuklara aktaran bir eğitimci olmalıdır."

Okul öncesi öğretmeninin sahip olması gereken kişisel özelliklerden birinin "gelişime açık olmak" olduğunu ifade eden yanıtlara örneklerden bazıları şöyledir:

(E2): "Okul öncesi öğretmeni kendini geliştirmeye istekli ve yeniliklere açık olmalıdır."

(E19): "Bir okul öncesi öğretmeni muhakkak bilimsel yenilikleri takip etmeli ve kendini her anlamda geliştirmelidir."

\section{Okul Öncesi Öğretmeninin Sahip Olması Gereken Mesleki Beceriler}

Ebeveynlerle yapılan görüşmelerden elde edilen verilerin analizinde ebeveynler okul öncesi öğretmenlerinin sahip olmaları gereken mesleki becerileri "farklı öğrenme ortamları oluşturma", ve "öğrenme sürecine liderlik etme" olarak ifade etmişlerdir.

Tablo 5

Okul Öncesi Öğretmeninin Sahip Olması Gereken Mesleki Beceriler

\begin{tabular}{llccc}
\hline Tema & Kod & $n$ & $f$ & $\%$ \\
\hline \multirow{3}{*}{ Mesleki Beceriler } & Farklı Öğrenme Ortamları Oluşturma & 38 & 24 & 63 \\
& Öğrenme Sürecine Liderlik Etme & 38 & 14 & 37 \\
\hline
\end{tabular}

Tablo 5'te de görüleceği üzere görüşmeye katılan ebeveynlerin çoğunluğu okul öncesi öğretmeninin sahip olması gereken en önemli mesleki becerinin "farklı öğrenme ortamları oluşturma" olduğunu belirtmişlerdir.

Okul öncesi öğretmeninin sahip olması gereken mesleki becerilerden birinin "farklı öğrenme ortamları oluşturma" olduğunu ifade eden yanıtlardan bazıları şöyledir:

(E7): "Okul öncesi öğretmenleri güvenliği ön planda tutarak çocukların farklılıklarını ortaya çıkaran, ihtiyaçlarını göz önünde bulunduran yaratıcı öğrenme ortamları dizayn etmelidir."

(E31): “Okul öncesi öğretmenleri çocukları tüm gelişim alanlarında destekleyecek uygun materyallerin kullanıldığı etkileşimli ortamlar hazırlamalıdır."

Okul öncesi öğretmeninin sahip olması gereken mesleki becerilerden birinin "öğrenme sürecine liderlik etme" olduğunu ifade eden yanıtlardan bazıları şöyledir:

(E13): “Okul öncesi öğretmenleri çocukların sürece aktif olarak dahil olduğu özellikle günlük yaşam becerilerinin kazandırılmasına yönelik oyun etkinliklerinin uygulanmasına öncülük etmelidir, ancak burada çocukların istekli olması muhakkak göz önünde bulundurulmalıdır."

(E27): “Öğretmenler faaliyetlerinde çocukların tüm teknolojik firsatları etkin olarak kullanmalarını sağlar ve iş birliği içerisinde öğrenmelerine yardımcı olur.” 


\section{Okul Öncesi Öğretmeninin Çocukları İlkokul Birinci Sınıfa Hazırlama}

\section{Durumu}

Ebeveynlerle yapılan görüşmelerden elde edilen verilerin analizinde ebeveynler okul öncesi öğretmenlerinin çocuklarını ilkokul birinci sınıfa hazırlama durumuna ilişkin "yeterli", "yetersiz” ve "kararsız” olarak fikir beyan etmişlerdir.

Tablo 6

Okul Öncesi Öğretmeninin Çocukları İlkokul Birinci Sınıfa Hazırlama Durumu

\begin{tabular}{llccc}
\hline Tema & Kod & $n$ & $f$ & $\%$ \\
\hline \multirow{2}{*}{ İlkokula Hazirlama } & Yeterli & 38 & 26 & 68 \\
& Kararsiz & 38 & 7 & 19 \\
& Yetersiz & 38 & 5 & 13 \\
\hline
\end{tabular}

Tablo 6'da da görüleceği üzere görüşmeye katılan ebeveynlerin çoğunluğu okul öncesi öğretmenlerinin çocukları ilkokul birinci sınıfa hazırlama durumunu "yeterli" bulduklarını belirtmişlerdir.

Okul öncesi öğretmeninin çocukları ilkokul birinci sınıfa hazırlama durumunu "yeterli" bulan ebeveyn yanıtlarından bazıları şöyledir:

(E4): "Çocuklara kalem tutmayı, sayıları, harfleri tanıtıyorlar böyle olunca çocuklar birinci sınıfta yazı yazmayı ve okumayı daha kolay öğreniyorlar."

(E26): “Çocuklar parmak kaldırma, ödev yapma gibi beceri ve alışkanlıkları kazanmış ve okul kurallarını algılamış bir şekilde ilkokula başladıkları için okul öncesi öğretmenlerini yeterli buluyorum."

Okul öncesi öğretmeninin çocukları ilkokul birinci sınıfa hazırlama durumu konusunda "kararsı"” olan ebeveyn yanıtlarından bazıları şöyledir:

(E29): “Okul öncesi öğretmeni daha çok çocukları eğlendirerek bir şeyler öğretmeye çalışıyor, oyunlar oynatıyor ancak birinci sınıfta çocuk yarış atı şeklinde çalıştırılmaya başlanıyor. Bu sebepten okul öncesi dönem ve ilkokul arasındaki geçiş konusunda fikir belirtmek istemiyorum."

(E36): "Anaokulu ve birinci sınıf ortamının birbirinden tamamen farklı olduğunu düşündüğüm için kararsızım."

Okul öncesi öğretmeninin çocukları ilkokul birinci sınıfa hazırlama durumunu "yetersiz" bulan ebeveyn yanıtlarından bazıları şöyledir:

(E14): “Okul öncesi öğretmenleri eğer çocukları birinci sınıfa tam olarak hazırlayabilselerdi birinci sınıfta hala annelerinden ayrılmamak için ağlayan çocuklar olmazdı diye düşünüyorum."

(E34): "Okul öncesi öğretmenleri daha özverili olsa çocuklar matematik ve yazı yazma becerileri konusunda birinci sınıfa daha hazırlıklı başlayabilirler ve aileler de sıkıntı çekmez." 


\section{Okul Öncesi Öğretmenlerinin Çalışma Süreleri}

Ebeveynlerle yapılan görüşmelerden elde edilen verilerin analizinde ebeveynler okul öncesi öğretmenlerinin çalışma sürelerini “oldukça uzun” ve "kısa" olarak tanımlamışlardır.

Tablo 7

Okul Öncesi Öğretmenlerinin Çalışma Süreleri

\begin{tabular}{llccc}
\hline Tema & Kod & $n$ & $f$ & $\%$ \\
\hline \multirow{2}{*}{ Çalışma Süreleri } & Oldukça Uzun & 38 & 29 & 76 \\
& Kısa & 38 & 9 & 24 \\
\hline
\end{tabular}

Tablo 7'de de görüleceği üzere görüşmeye katılan ebeveynlerin çoğunluğu okul öncesi öğretmenlerinin çalışma sürelerini “oldukça uzun” bulduklarını ifade etmişlerdir.

Okul öncesi öğretmenlerinin çalışma sürelerini “oldukça uzun” bulan ebeveyn yanıtları şu şekildedir:

(E18): "Okul öncesi öğretmenlerinin çalışma sürelerinin çok uzun olduğunu düşünüyorum. Yarım gün bile olsa o yaştaki çocukları en az dört saat kontrol altında tutmak oldukça zordur.”

(E33): “Okul öncesi dönem kritik bir dönemdir ve yapılan işlemler tüm hayatı etkilediği için bir hayli zordur, bu sebepten çalışma sürelerinin okul öncesi öğretmenlerini zorlayacak derecede uzun olduğunu düşünüyorum.” şekildedir:

Okul öncesi öğretmenlerinin çalışma sürelerini "kısa" bulan ebeveyn yanıtları şu

(E22): "Çocukların yaşı küçüldükçe ilgi ve dikkat süreleri kısaldığından okul öncesine ayrılan sürenin de kısa olması gayet doğaldır."

(E36): "Okul öncesi öğretmenleri diğer branşlara göre daha kısa süreli çalışmaktadır ama emekleri bu kısa sürenin üzerini kapatmaktadır."

\section{Okul Öncesi Öğretmeninin Ailelerle Diyaloğu}

Ebeveynlerle yapılan görüşmelerden elde edilen verilerin analizinde ebeveynler okul öncesi öğretmenlerinin ailelerle diyaloğunu "sürekli iş birliği”, "ihtiyaç durumunda iş birliği ve "mesafeli" olarak tanımlamışlardır.

Tablo 8

Okul Öncesi Ö̆̆retmeninin Ailelerle Diyaloğu

\begin{tabular}{llccc}
\hline Tema & Kod & $n$ & $f$ & $\%$ \\
\hline \multirow{3}{*}{ Ailelerle Diyalog } & Sürekli İşbirliği & 38 & 21 & 55 \\
& İ̀tiyaç Durumunda İş birliği & 38 & 11 & 29 \\
& Mesafeli & 38 & 6 & 16 \\
\hline
\end{tabular}


Tablo 8'de de görüleceği üzere görüşmeye katılan ebeveynlerin çoğunluğu okul öncesi öğretmenlerinin ailelerle diyaloğunu "sürekli iş birliği" halinde olarak belirtmişlerdir.

Okul öncesi öğretmenlerinin ailelerle diyaloğunu "sürekli iş birliği" halinde olma olarak tanımlayan ebeveyn yanıtları şu şekildedir:

(E11): "Okul öncesi öğretmeni sürekli olarak aktivite ve etkinlikler yoluyla ailelerle iş birliği içerisinde olmalıdır. Bu durum çocuğun öğretmenini aileden biri olarak görmesini sağlar."

(E28): "Okul öncesi öğretmeni sadece çocuğun problemlerini değil ufak bile olsa başarılarını da veli ile paylaşmalı ve sürekli iletişim halinde olmalıdır."

Okul öncesi öğretmenlerinin ailelerle diyaloğunu "ihtiyaç durumunda iş birliğgi" halinde olma olarak tanımlayan ebeveyn yanıtları şu şekildedir:

(E13): "Diyalog önemlidir elbette ama öğretmenin aile ile çok fazla içli dişlı olmasını etik bulmuyorum. Aile sadece çocuğun gelişimi ile ilgili bilgilerden haberdar olsa yeterlidir."

(E31): “Öğretmenin ailelerle gerektiği zaman diyalog kurması önemlidir. Ancak öğretmenin veli ile değil öğrencisi ile daha çok ilgilenmesi gerekmektedir. Ayrıca öğretmenin her aileye eşit mesafede olması gerekir."

Okul öncesi öğretmenlerinin ailelerle diyaloğunu "mesafeli" olarak tanımlayan ebeveyn yanıtları şu şekildedir:

(E24): “Okul öncesi öğretmeni bile olsa ailelerle çok fazla içli dışlı olmasını kesinlikle doğru bulmuyorum çünkü bu durum öğretmenin öğrencisini ailesiyle beraber değerlendirmesine veya taraflı davranmasına neden olabiliyor."

(E30): “Okul öncesi öğretmeninin görevi çocuğun gelişimini ilerletmektir, sürekli aile ile haşır neşir olmak değildir.”

\section{Sonuç ve Tartıșma}

$\mathrm{Bu}$ çalışmada okul öncesi dönemde çocuğu olan, üniversite mezunu, devlet sektöründe görev yapan, farklı meslek çalışanı ebeveynlerin okul öncesi öğretmenlerine dair görüşleri incelenmiştir. Ebeveyn beklentileri okul öncesi eğitimde önemli bir rol oynamaktadır (Froiland, Peterson, \& Davison, 2012). Çalışmadan elde edilen bulgular değerlendirildiğinde, ebeveynlerin genel olarak okul öncesi eğitime ve okul öncesi öğretmenlerine karşı olumlu düşüncelere sahip oldukları söylenebilir. 0-6 yaş çocuklarının eğitimi konusunda öğretmenler ve ebeveynler arasındaki sorumlulukların paylaşılması gerekliliğine yönelik birçok araştırma yapılmıştır (Guerra \& Luciano, 2010). Bu araştırmalar, güçlü okul-aile bağlarının anaokulu eğitimlerinde daha yüksek bir etkiyle sonuçlandığını ortaya koymaktadır (Galindo \& Sheldon, 2012; Kim ve diğerleri, 2012). Alanyazın tarandığında anneler okul öncesi eğitimin çocukların sosyalduygusal, dil, psikomotor ve bilişsel gelişimlerini, dinleme ve konuşma becerilerini, hatta aileleri olumlu bir şekilde desteklediğini ifade etmişlerdir (Aslanargun \& Tapan, 2011; Ou \& Reynolds, 2004; Powell, 1999). Bunun yanı sıra kaliteli bir şekilde sürdürülen okul-ev iş birliği çocukların okuldaki gelişimini, motivasyonunu ve başarısını; ebeveyn-çocuk, öğretmen-çocuk ve ebeveyn-öğretmen iletişimini de olumlu bir şekilde etkilemektedir (Gonzalez-DeHass, Willems, \& Doan Holbein, 2005; Henderson \& Berla, 1994; Pomerantz, Moorman, \& Litwack, 2007).

Görüşmelerde okul öncesi öğretmeninin toplumdaki konumuna ilişkin ebeveynlerin çoğunluğu "hak ettiği değerden uzak bir konumda" şeklinde diğer ebeveynler ise "değer verilen bir konumda" olarak iki farklı görüş bildirmiş̧lerdir. Okul öncesi öğretmenlerinin hak ettiği değerden uzak bir konumda olduğunu düşünen 
ebeveynlerin çoğunluğu annedir ve toplumda okul öncesi öğretmenlerinin bakıcı gibi düşünüldüğünü üzülerek ifade etmişlerdir. Ayrıca çocukların bitmek bilmeyen enerjileri dolayısıyla mesleğin çok yorucu olduğu, çocuklara temel bazı becerilerin kazandırılmasında ilk adımı atmanın zorluğu, yaşlarından dolayı çocuklara disiplin aşılamanın güçlüğü, sınıf kurallarını ilk öğretme sorumluluğu, yani çocukla ilgilenmenin, çocuğa bir şey öğretmenin ne kadar zor ve özveri gerektiren bir iş olduğunu bildikleri için okul öncesi öğretmenlerine kıymet verilmesi gerektiğini belirtmişlerdir. Annelerden farklı olarak babalar ise okul öncesi öğretmenlerinin toplumda diğer tüm öğretmenler gibi hak ettiği değeri gördüğünü düşünmektedir. Geçmişten günümüze kadar öğretmenlik mesleği toplumun önemli bir değeridir ve "ideal", "yüce" gibi değer içerikli kelimelerle tanımlanmaktadır (Karamustafaoğlu \& Özmen, 2004; Özyar, 2001).

Ebeveynlerle yapılan görüşmelerden elde edilen verilerin analizinde ebeveynlerin çoğunluğu okul öncesi öğretmenliğinin diğer öğretmenlik alanlarından farklılıklarına yönelik olarak "yaşam becerisi kazandırma” şeklinde, diğer ebeveynler ise "yumuşak mizaca sahip olma", "farklı ve çeşitli materyaller kullanma" ve "gelişimsel aşamaları bilme" olarak farklı görüşler bildirmişlerdir. İlginç bir veri olarak babaların birçoğu okul öncesi öğretmenlerinin aslında çocukların ailede yeterince kazanamadıkları giyinme, yemek yeme, tuvalet ihtiyacını giderme gibi yaşam becerilerini kazandırdıklarını belirtmişlerdir. Annelerin çocuklarına karşı fazla korumacı davranmalarını ve çocuklarının yorulmasına kıyamamalarını da bu becerilerin evde tam anlamıyla kazanılamamasının sebebi olarak ifade etmişlerdir. Özbakım becerileri olarak ta ifade edilen günlük yaşam becerileri; evde, okulda ya da diğer ortamlarda bireyin temizlik, giyinme, yaşam alanlarında gerekli düzenlemeleri yapma, yeterli ve dengeli beslenme, dinlenme, günlük yaşam becerileri için gerekli araç ve gereçleri kullanma, kendini tehlikelerden ve kazalardan koruma ve sağlı̆̆ ile ilgili önlemler alma gibi bağımsız olarak yaşamını sürdürebilmek için gerekli olan tüm becerileri tanımlamaktadır (Milli Eğitim Bakanlığı [MEB], 2013; Varol, 2005). Annelerin birçoğu ise babalara göre daha duygusal davranarak okul öncesi öğretmenlerinin sevecen ve daha yumuşak bir mizaca sahip olmaları gerektiğini belirtmişlerdir. Bu dönemdeki yanlış tutum ve davranışların çocuğun tüm yaşamını etkileyecek sorunlara yol açabileceği bilinmektedir. Bundan dolayı anneler okul öncesi öğretmenlerinin güler yüzlü ve anlayışılı olmalarının önemine dikkat çekmişlerdir.

Okul öncesi öğretmeninin sahip olması gereken kişisel özelliklere yönelik ebeveynlerin çoğunluğu "sevecen olmak", diğer ebeveynler "güler yüzlü olmak", "hoşgörülü olmak", "sorumluluk sahibi olmak" ve "gelişime açık olmak" olarak farklı görüşler bildirmişlerdir. Annelerin öğretmenlerden beklentileri daha duygusal bir şekilde sevecenlik, güler yüz ve hoşgörüyken, babaların beklentileri duygusallıktan uzak bir şekilde çocuklarına rol model olabilmeleri gerekçesiyle sorumluluk sahibi ve gelişime açık olmalarıdır. Çelikten, Şanal ve Yeni (2005) araştırmalarında öğretmenlerin sevgi, fedakârlık, sabır gibi olumlu nitelikler taşımaları gerektiğini belirtmişlerdir. Cui, Valcke ve Vanderlinde (2016) çalışmalarında ebeveynlerin okul öncesi öğretmenlerinin en önemli yetkinliklerini "saygi" ve "sevgi" olarak tanımladıklarını belirtmişlerdir. Tüm meslekler için gelişim çok önemlidir bu sebepten öğretmenlik sürekli olarak kendini geliştirmeyi ve yenilemeyi gerektiren bir meslektir (Krečič \& Grmek, 2008). 
Ebeveynlerin çoğunluğu okul öncesi öğretmenlerinin sahip olmaları gereken mesleki becerileri "farklı öğrenme ortamları oluşturma" olarak, diğer ebeveynler ise "öğrenme sürecine liderlik etme" olarak ifade etmişlerdir. Genel olarak anneler çocuklarının okul öncesi eğitim kurumunda akademik bilgi ve becerilerle donatılması gerektiğini savundukları için annelerin çoğunluğu bu bilgi ve becerilere ulaşılabilmesi adına farklı öğrenme ortamlarının oluşturulması gerektiğini belirtmişlerdir. Babaların çoğunluğunun okul öncesi öğretmenlerinden beklentisi ise akademik bilgi ve beceriler kazandırmak yerine çocuklarının doğal öğrenmelerine müdahale etmeden sadece sürece liderlik etmelerini sağlamaktır. Stronge, Ward ve Grant (2011) etkili öğretmenliğin önemli niteliklerinden birini olumlu öğrenme ortamları oluşturmak olarak belirtmişlerdir. Sağlıklı öğretmen-öğrenci ve öğrenci-öğrenci etkileşiminin sağlandığı öğrenme ortamları çocukları öğrenmeye karşı motive eder ve başarıyı arttırır (Caballero, 2010; Christiana, 2009; Knoell, 2012; Nugent, 2009). Darling-Hammond (2010) etkili öğretmenleri yüksek standartlar belirleyerek öğrencilerini teşvik eden, motive eden ve öğrencilerinin kendi öğrenmelerini gerçekleştirebilmeleri konusunda onlara liderlik eden bireyler olarak tanımlamıştır.

Okul öncesi öğretmenlerinin çocuklarını ilkokul birinci sınıfa hazırlama durumuna ilişkin ebeveynlerin çoğunluğu "yeterli" olarak, diğer ebeveynler "yetersiz" ve "kararsız" olarak fikir beyan etmişlerdir. Okul öncesi öğretmenlerini ilkokula hazırlama açısından yetersiz gören ya da bu konu hakkında kararsız olan ebeveynlerin yeterli gören ebeveynlerden farklı olarak okul öncesi dönemde akademik becerilerin gelişimini oldukça önemseyen bireyler olduğu söylenebilir. Ayrıca annelerin çoğunluğu çocuğunun akademik bilgi ve beceri seviyesinin artmasını çok önemsediklerini dile getirmişlerdir. Çoğu ebeveyn okul öncesi eğitim kurumlarından çocuklarının sosyal becerilerini geliştirerek ilkokula hazırlamasını beklemektedir (Acchpal, 2000; Einarsdottir, 2010; Sevinç, 2006; Şahin, Sak, \& Şahin-Sak, 2013). Aslanargun ve Tapan (2011) çalışmalarında ailelerin okul öncesi eğitim kurumlarından çocuklarının daha iyi eğitim almaları, birinci sınıfta daha başarılı olmaları, okula adapte olmaları, bilginin farkına varmaları ve okulla ilgili sorumluluk almaları gibi beklentileri olduğunu ifade etmişlerdir.

Ebeveynlerin çoğunluğu okul öncesi öğretmenlerinin çalışma sürelerini "oldukça uzun" olarak, diğer ebeveynler ise "kısa" olarak tanımlamışlardır. Ebeveynlerin çoğu okul öncesi öğretmenleri küçük yaş çocuklarıyla iletişim halinde olduğu için bu durumun gerçekten zor olduğunu belirtmiş ve çalışma sürelerini “oldukça uzun" olarak, tanımlamışlardır. Okul öncesi öğretmenlerinin çalışma sürelerini babaların tümü çok uzun olarak nitelendirmiştir. Okul öncesi öğretmenlerinin çalışma sürelerinin kısa olduğunu ifade eden cevapların tümünü anneler vermiştir ve yarım günün çocuğa yeni bir şeyler öğretmek için çok yetersiz bir süre olduğunu söyleyerek yine akademik beklentilerini dile getirmişlerdir. Yapılan araştırmalar okul öncesi eğitim kurumlarında teneffüs hakkı olmadan aralıksız geçirilen altı etkinlik saatinin öğretmenlerin verimini düşürdüğünü ve dolayısıyla çocukları da olumsuz etkilediğini ortaya koymaktadır (Can \& Bayramoğlu, 2016; Can \& Serençelik, 2017)

Görüşmelerden elde edilen verilerin analizinde ebeveynlerin çoğunluğu okul öncesi öğretmenlerinin ailelerle diyaloğunu "sürekli iş birliği" halinde olarak, diğer ebeveynler ise "ihtiyaç durumunda iş birliği ve "mesafeli" olarak tanımlamışlardır. Annelerin çoğunluğu okul öncesi öğretmenleriyle sürekli iş birliği içinde olmanın ortaya 
çıkabilecek problemlere kısa sürede müdahale etmek açısından faydalı olduğunu, ayrıca çocuğun her alandaki gelişim takibi için de çok önemli olduğunu vurgulamışlardır. Babaların çoğunluğu ise gerekli olan durumlarda iş birliği yapılmasının herkes için çok daha yararlı olduğuna dikkat çekmişlerdir. Yapılan çalışmalar aile katılım etkinlikleri yoluyla okul-aile iş birliğinin sağlandığı durumlarda ailelerin çocuklarının güçlü ve zayıf yönlerini rahatlıkla görebildiklerini ortaya koymuştur. Bunun yanı sıra çocukların başarılarının arttığı, özgüvenlerinin geliştiği, aile içi iletişime de katkı sağladığı tespit edilmiştir (Driessen, Smit, \& Sleegers, 2005; Marcon, 1999; Ünüvar, 2010).

\section{Öneriler}

$\mathrm{Bu}$ çalışmadan elde edilen veriler neticesinde çeşitli öneriler sunulabilir. Öğretmen yetiştiren fakültelerde ebeveyn ve öğretmen iş birliğinin önemi sıklıkla vurgulanarak bu iş birliğinin nasıl sağlanacağı noktasında bilgilendirmeler yapılabilir. Staj uygulamalarıyla bu iş birliğini hayata geçirmeleri noktasında harekete geçirilebilirler. Olumlu tutum geliştirmeye yönelik olarak hem mevcut öğretmenlere hem de bu iş birliğinin ayrılmaz parçası olan ebeveynlere konuyla ilgili bilinç kazandırabilmek amacıyla hizmet içi eğitimler, seminerler verilebilir. Ayrıca araştırmacılara ebeveynlerin bakış açısıyla öğretmen olgusunu tartışabilecekleri, farklı araştırma yöntemlerini ya da farklı çalışma gruplarını içeren araştırmalar yapmaları ve bu araştırma sonuçlarını karşılaştırmaları önerilebilir. 


\section{Summary}

Purpose and Significance: The first place where child care and education start is undoubtedly the family environment. The educational period which starts within the family for the child continues in a preschool educational institution, but parents still play a big and important role in bringing up children. Therefore, the cooperation of the school and the family cannot be ignored. The coordinated action of parents and the family is the most effective educational method for a child (İşmen \& Y1ld1z, 1996). It is a primary condition that families must have positive opinions about preschool teachers and trust them so that preschool teachers can support families in matters they lack and parents can ask teachers for help when they need. The general aim of this study is to reveal the opinions of parents who have children in the preschool period and work in different professions on preschool teachers. Answers were sought to seven questions in accordance with this general aim: (1) What is the status of the preschool teacher in the society? (2) In what terms is preschool teaching different from other teaching areas? (3) What personality traits must a preschool teacher have? (4) Which professional skills must a preschool teacher have to be competent? (5) How much can a preschool teacher prepare children for the first grade in primary school? (6) What do you think about the working hours of preschool teachers? (7) What must the dialogue of a preschool teacher with families be? In this sense, this study has significance for examining parents' expectations and opinions about preschool teachers and making different suggestions.

Methods: In this study, the phenomenology pattern, one of the qualitative research techniques, was used. This study was conducted in the phenomenology pattern in order to present the opinions of parents who have children in the preschool period and work in different professions on the term "preschool teacher" in a detailed way, to reveal and define them with their different aspects and to have a detailed understanding. Among the purposeful sampling methods, the criterion sampling method was used for the selection of the study group. In this sense, the criterion was to select university graduates, state workers, and children continuing preschool education while determining the participants of the sampling. Accordingly, 38 parents in total, who met the criteria mentioned and worked in different professions, constituted the study group of the research. The data in the study were collected using the "Personal Information Form" including questions for parents and the semi-structured "Parent Interview Form", which contained open-ended questions. The data obtained from the interviews with parents were interpreted through the descriptive analysis technique, which is one of the qualitative data analysis techniques. In this study, the themes are the sub-aims supporting the general aim of the study, in other words, the themes were formed of the selected topics. The data obtained are the codes organized and interpreted under the subaims.

Results: It can be said when the findings obtained from the study are evaluated that parents generally have positive opinions on preschool education and preschool teachers. According to the analysis of the data received from the interviews with parents, parents presented two different views for the status of preschool teachers in the society as "in a position far from the deserved value" and "in a valued position". Parents stated that 
preschool teachers are different from other teaching areas in terms of "providing life skills", "having a soft temperament", "using different and various materials" and "knowing the developmental stages". Parents specified the personality traits which a preschool teacher must have as "being kind-hearted", "being cheerful", "being tolerant", "being aware of responsibilities", and "being open to improvement", and the professional skills as "creating different learning environments" and "leading the learning process". Parents presented different views about how preschool teachers prepare children for the first grade in primary school as "competent", "incompetent" and "not sure", and the working hours of preschool teachers as "quite long" and "short". Finally, parents defined the dialogues of preschool teachers with families as "continuous cooperation", "cooperation when needed" and "distant".

Discussion and Conclusions: Parents' expectations play a critical role in preschool education (Froiland, Peterson, \& Davison, 2012). It can be said when the findings obtained from the study are evaluated that parents generally have positive opinions on preschool education and preschool teachers. Many studies have been conducted on the requirement of sharing the responsibilities between teachers and parents when it comes to the education of 0-6-aged children (Guerra \& Luciano, 2010). These studies reveal that strong school-family ties result in a higher effect in kindergarten education (Galindo \& Sheldon, 2012; Kim et al., 2012). In the literature, mothers have expressed the idea that preschool education supported the social-emotional, language, psychomotor and cognitive development of children and even families positively (Aslanargun \& Tapan, 2011; Ou \& Reynolds, 2004; Powell, 1999). Most of the parents specified the status of preschool teachers in the society as "in a position far from the deserved value". From the past to present, the teaching profession has been an important value of the society and defined with valuable words such as "ideal" and "honorable" (Karamustafaoğlu \& Özmen, 2004; Özyar, 2001). Most of the parents consider preschool teachers different from other teaching areas since they provide children with life skills. When it comes to the personality traits preschool teachers must have, mothers emotionally expect them to be kind-hearted, cheerful and tolerant whereas fathers expect them - far from being emotional - to be aware of their responsibilities and open to improvement so that they can be seen as a role model for their children. Cui, Valcke and Vanderlinde (2016) stated in their study that parents defined the most important competencies of preschool teachers as "respect" and "love". Most of the parents defined the professional skills that preschool teachers must have as "creating different learning environments". Stronge, Ward and Grant (2011) specified one of the important qualities of effective teaching as creating positive learning environments. Most of the parents found teachers "competent" regarding how preschool teachers prepare children for the first grade in primary school. Differently from the parents considering teachers competent, the parents who find preschool teachers incompetent in terms of preparation for the primary school or who are not sure about it can be said to be individuals giving significance to the development of academic skills in the preschool period. Most of the parents found the situation difficult as preschool teachers are in contact with small children and defined the working hours as "quite long". While most of the mothers emphasized the great importance of cooperating continuously with preschool teachers 
for the child development, most of the fathers stressed that cooperation is more useful for everyone when there is a need. 


\section{Kaynakça}

Achhpal, B. (2000). A comparison of European American and Puerto Rican parents' beliefs and expectations concerning early intervention programs for preschool children (Unpublished doctoral dissertation). University of Connecticut, USA.

Akyüz, Y. (2008). Türk eğitim tarihi (M.Ö. 1000-M.S. 2008). Ankara: Pegem Akademi Yayıncilik.

Aral, N., Kandır, A., \& Can-Yaşar, M. (2000). Okul öncesi eğitim 1. Ankara: Ya-Pa Yayin Pazarlama.

Aslanargun, E., \& Tapan, F. (2011). Okul öncesi eğitimin çocuklar üzerindeki etkileri. Abant İzzet Baysal Üniversitesi Eğitim Fakültesi Dergisi, 11(2), 219-239.

Avc1, Ü., \& Seferoğlu, S. S. (2011). Bilgi Toplumunda Öğretmenin Tükenmişliği: Teknoloji Kullanımı ve Tükenmişliği Önlemeye Yönelik Alınabilecek Önlemler. Akdeniz Eğitim Araştırmaları Dergisi, 9, 13-26.

Barber, M., \& Mourshed, M. (2007). How the world's best performing schools systems come out on top. London: McKinsey and Company. www.mckinsey.com/clientservice/socialsector/resources/pdf/Worlds_School_syste ms_final.pdf. Erişim Tarihi: 14.04.2018

Başaran, İ. E. (1993). Eğitim psikolojisi, modern ĕgitimin psikolojik temelleri. Ankara: Kadıoğlu Matbaası.

Büyüköztürk, Ş., Çakmak K. E., Akgün Ö. E, Karadeniz Ş., \& Demirel, F. (2009). Bilimsel araştırma yöntemleri. Ankara: Pegem Akademi.

Caballero, J. A. R. (2010). The effects of teacher-student relationship, teacher, expectancy and culturally-relevant pedagogy on student academic achievement. (Unpublished doctoral dissertation). University of Redlands, USA. https://pqdtopen.proquest.com/doc/897551383.html?FMT=AI Erişim Tarihi: 20.05.2018

Can, E., \& Bayramoğlu, A. (2016). Eğitim yönetimi araştırmaları. "Ortaöğretimde okul yönetimine katılım”. Ankara: Pegem Akademi.

Can, E., \& Serençelik, G. (2017). Okul öncesi eğitim öğretmenlerinin okul yönetimine katılımlarının incelenmesi. Dicle Üniversitesi Ziya Gökalp Eğitim Fakültesi Dergisi, 30, 525-542.

Carr-Saunders, A. M., \& Wilson, P. A. (1944). "Professions", Encyclopedia of the Social Sciences, New York, NY: Macmillan.

Christiana, O. (2009). Influence of motivation on students' academic performance. Medwell Journals, 4(1), 30-36.

Cui, Z., Valcke, M., \& Vanderlinde, R. (2016). Empirical study of parents' perceptions of preschool teaching competencies in china. Open Journal of Social Sciences, 4, 17. doi: 10.4236/jss.2016.42001

Çeliköz, N., \& Çetin, F. (2004). Anadolu öğretmen lisesi öğrencilerinin öğretmenlik mesleğine yönelik tutumlarını etkileyen etmenler. Milli Ĕ̆itim Dergisi, 32(162), 136-145.

Çelikten, M., Şanal, M., \& Yeni, Y. (2005). Öğretmenlik mesleği ve özellikleri. Erciyes Üniversitesi Sosyal Bilimler Enstitüsü Dergisi, 19(2), 207-237. 
Çepni, S. (2012). Araştırma ve proje çalışmalarına giriş. Trabzon: Celepler Matbaacilik.

Darling-Hammond, L. (2010). Evaluating teacher effectiveness: How teacher performance assessments can measure and improve teaching. Washington, DC: Center for American Progress.

Dönmez, N. B. (1992). Okul öncesi eğitim kurumlarında çalışan personelin niteliği.1.Okul Öncesi Ĕ̆itim Semineri, (s. 25-27), Ankara.

Driessen, G., Smit, F., \& Sleegers, P. (2005). Parental involvement and educational achievement. British Educational Research Journal, 31, 509-532. doi: 10.1080/014119205001487132

Duman, T. (1991). Türkiye'de ortaöğretime ögretmen yetiştirme (Tarihi gelişimi). İstanbul: Milli Eğitim Basımevi.

Einarsdottir, J. (2010). Icelandic parents' views on the national policy on early childhood education. Early Years, 30(3), 229-242.

Erden, M. (1998). Öğretmenlik mesleğine giriş. İstanbul: Alkım Yayınları.

Froiland, J. M., Peterson, A., \& Davison, M. L. (2012). The long-term effects of early parent involvement and parent expectation in the USA. School Psychology International, 34, 33-50. doi: 10.1177/0143034312454361

Galindo, C., \& Sheldon, S. B. (2012). School and home connections and children's kindergarten achievement gains: the mediating role of family involvement. Early Childhood Research Quarterly, 27, 90-103. doi: 10.1016/j.ecresq.2011.05.004

Gonzalez-DeHass, A. R., Willems, P. P., \& Doan Holbein, M. F. (2005). Examining the relationship between parental involvement and student motivation. Educational Psychology Review, 17(2), 99-123.

Gök, F. (2003). "Hizmet öncesi ve hizmet içi öğretmen yetistirme", Ögretmen Yetistirme ve İstihdamı Sempozyumu, Ankara: Eğitim-Sen Yayınları.

Gökçe, E. (1997). Eğitim programının geliştirilmesinde öğretmenin rolü. Uluslararası Dünya Öğretmen Eğitimi Konferansı (27 Ağostus-2 Eylül 1995) kitabı içinde (s. 204-216), Ankara: Milli Eğitim Basımevi.

Guerra, M., \& Luciano, E. (2010). Sharing the responsibility of education: the relationship between teachers and parents in 0-6 year-old children services and schools. Procedia-Social and Behavioral Sciences, 2, 3308-3313. doi: 10.1016/j.sbspro.2010.03.506

Gündüz, H. B. (2003). Bir meslek olarak öğretmenlik. İçinde Karslı, M. D. (Ed.), Öğretmenlik mesleğine giriş. (s.319). Ankara: Pegem A Yayıncılık.

Güven, D. (2010). Profesyonel bir meslek olarak Türkiye'de öğretmenlik. Boğaziçi Üniversitesi Eğitim Dergisi, 27(2), 13-21.

Hacıoğlu, F., \& Alkan, C. (1997). Ögretmenlik uygulamaları. Ankara: Alkım Yayınevi.

Henderson, A. T., \& Berla, N. (1994). A new generation of evidence: The family is critical to student achievement. Washington, DC: National Committee for Citizens in Education.

İşmen, E., \& Yıldız, A. (1996). Okulöncesi dönemde aile-okul işbirliği ve ebeveynin eğitime katılımı. Yaşadıkça Ĕgitim, 44, 30-32. 
Karamustafaoğlu, O., \& Özmen, H. (2004). Toplumumuzda ve öğretmen adayları arasında öğretmenlik mesleğine verilen değer üzerine bir araştırma. Değerler Ĕ̈itimi Dergisi, 2(6), 35-49.

Karasar, N. (2009). Bilimsel araştırma yöntemleri. Ankara: Nobel Yayınları.

Kavcar, C. (1999). Nitelikli öğretmen sorunu. Eğitimde Yansımalar: V 21. Yüzyılın Eşiğinde Türk Eğitim Sistemi Ulusal Sempozyumu (25-27 Kasım 1999). Ankara: Öğretmen Hüseyin Hüsnü Tekışık Araştırma-Geliştirme Merkezi.

Kim, E. M., Coutts, M. J., Holmes, S. R., Sheridan, S. M., Ransom, K. A., Sjuts, T. M., \& Rispoli, K. M. (2012). Parent involvement and family-school partnerships: examining the content, processes, and outcomes of structural versus relationshipbased approaches. CYFS Working Paper. No. 2012-6, Nebraska Center for Research on Children, Youth, Families and Schools.

Knoell, C.M. (2012). The role of the student-teacher relationship in the lives of fifth graders: A mixed methods analysis (Unpublished doctoral dissertation). University of Nebraska, Lincoln. https://digitalcommons.unl.edu/dissertations/AAI3499134/ Erişim Tarihi: 20.05.2018

Krečič, M.J., \& Grmek, M.I. (2008). Cooperative learning and team culture in schools: Conditions for teachers' professional development. Teaching and Teacher Education, 24(1), 59-68. doi: 10.1016/j.tate.2007.02.011

Luke, A., Luke C., \& Mayer, D. (2000). Redesigning teacher education. Teacher Education, 11(1), 5-11. doi: 10.1080/10476210050020318

Marcon, R. A. (1999). Positive relationships between parent school involvement and public school inner-city preschoolers' development and academic performance. School Psychology Review, 28(3), 395-412.

MEB. (2013). MEB okul öncesi ĕgitim programı. Ankara: Milli Eğitim Bakanlığı.

Merriam, S. B. (2015). Nitel araştırma: Desen ve uygulama için bir rehber. (3. Baskı). (Çev. Edt. S. Turan). Ankara: Nobel Yayıncılık.

Miles, M. B., \& Huberman, A. M. (1994). Qualitative data analysis-A sourcebook of new methods. Thousand Oaks, CA: Sage Publications.

Nugent, T.T. (2009). The impact of teacher-student interaction on student motivation and achievement (Unpublished doctoral dissertation). University of Central Florida, Florida. http://etd.fcla.edu/CF/CFE0002884/Nugent_Tisome_T_200912_EdD.pdf Erişim Tarihi: 20.05 .2018

Oğuzkan, Ş., \& Oral, G. (1997). Okul öncesi eğitimi. İstanbul: Milli Eğitim Basımevi.

Oktay, A. (1991). Öğretmenlik mesleği ve öğretmenin nitelikleri. Marmara Üniversitesi Atatürk Ĕ̆itim Fakültesi Eğitim Bilimleri Dergisi, 3(3), 187-193.

Oktay, A. (2004). Yaşamın sihirli yılları. İstanbul: Epsilon Yayıncılık.

Ou, S., \& Reynolds A. J. (2004). Preschool education and school completion. In: Tremblay R. E., Barr R.G., deV Peters R., eds. Encyclopedia on Early Childhood Development. Montreal, Quebec: Centre of Excellence for Early Childhood Development.

Özyar, A. (2001). Türkiye'de öğretmen yetiştirme politikaları. Bilim ve Aklın Aydınlı̆̆ında Ĕ̈itim Dergisi, 2(21). 
Pomerantz, E. M, Moorman, E. A., \& Litwack, S.D. (2007). The how, whom, and why of parents' involvement in children's academic lives: More is not always better. Review of Educational Research, 77(3), 373-410.

Powell, D. R. (1999). Early childhood development. In A.J. Reynolds, H.J. Walberg, (Eds.), Promoting positive outcomes in children, 45-71, Washington, DC: CWLA.

Senemoğlu, N. (2001). Öğrenci görüşlerine göre öğretmen yeterlilikleri. Eğitimde Yansımalar: VI. (11-13 Ocak). Ankara: Öğretmen Hüseyin Hüsnü Tekışık Eğitim Araştırma Geliştirme Vakfı Yayınları, 193-215.

Sevinç, M. (2006). Okul öncesi eğitimi alan çocukların annelerinin okuldan beklentileri. Kazım Karabekir Ĕ̌itim Fakültesi Dergisi, 13, 218-225.

Shulman, L. (1986). Those who understand: Knowledge growth in teaching. Educational Researcher, 15 (2), 4-14.

Sönmez, V., Senemoğlu, N., Tezcan, M., Alkan, C., Bircan, İ., Karakütük, K., \& Yanpar Şahin, T. (2000). Öğretmenlik mesleğine giriş. Ankara: Anı Yayıncılık.

Stephens, P. \& Crawley, T. (1994). Becoming an effective teacher. http://www.google.com/books?hl=tr\&lr=\&id=8MHZ8rxpD2wC\&oi=fnd\&pg=PR5 $\& \mathrm{dq}=$ StepheP.+Becoming + an+effective + Teacher\&ots=kPZTlGFTHQ\&sig=VGzT mfFxLX3OL5_4FziEPtDPd0\#v=onepage $\& q=\& f=$ false Erişim Tarihi: 17.05.2018

Stronge, J. H., Ward, T. J., \& Grant, L. W. (2011). What makes good teachers good? A cross-case analysis of the connection between teacher effectiveness and student achievement. Journal of Teacher Education, 62 (4), 339-355.

Sümbül, A. M. (1996). Öğretmen niteliği ve öğretimdeki rolleri. Kuram ve Uygulamada Ĕ̆itim Yönetimi Dergisi, 8(3), 597-608. http://dergipark.ulakbim.gov.tr/kuey/article/view/5000050999/5000048227 Erişim Tarihi: 30.04 .2018

Svensson, L. G. (2006). New professionalism, trust and competence. Current Sociology, 54(4), 579-593.

Şahin, B. K., Sak, R., \& Şahin-Sak, İ. T. (2013). Parents' views about preschool education. Procedia Social and Behavioral Sciences, 89, 288-292.

Tekışık, H. H. (1987). Türkiye'de öğretmenlik mesleği ve sorunları. Hacettepe Üniversitesi Eğitim Fakültesi Dergisi, 2(2), 24-33.

Tuğrul, B. (2006). Okul öncesi eğitimde kalite. III. Uluslararası Öğretmen Yetiştirme Sempozyumu Bildiri Özetleri Kitabı, Çanakkale.

Ünüvar, P. (2010). Aile katılımı çalışmalarına yönelik ebeveyn ve öğretmen görüşlerinin karşılaştırılması. Kastamonu Eğitim Dergisi, 18(3), 719-730.

Varol, N. (2005). Beceri öğretimi ve özbakım becerilerinin kazandırılması. Ankara: Kök Yayıncilik.

Yaman, E., Yaman, H., \& Eskicumal1, A. (2001). Öğretmenlik mesleğinin sosyoekonomik statüsü/bu mesleğin bir bayan mesleği haline dönüşmesi durumu ve eğitim fakültesi üzerine bir araştırma. Sakarya Üniversitesi Eğitim Fakültesi Dergisi, 2, 33-68.

Y1ldırım, A., \& Şimşek, H. (2011). Sosyal bilimlerde nitel araştırma yöntemleri. Ankara: Seçkin Yayınları. 
Yurdakul, S., Gür, B. S., Çelik, Z., Kurt, T., \& Olçum, A. (2016). Öğretmenlik mesleği ve mesleğin statüsü. Ankara: Eğitim-Bir-Sen Stratejik Araştırmalar Merkezi.

Zembat, R. (1992). Okul öncesi ĕgitim kurumlarında yönetim ve yönetici özellikleri (Yayımlanmamış Doktora Tezi). Marmara Üniversitesi, Sosyal Bilimler Enstitüsü, İstanbul. 